\title{
Fault-matrix interactions in nonwelded tuff of the Paintbrush Group at Yucca Mountain
}

\author{
Rohit Salve*, Curtis M. Oldenburg, and Joseph S. Wang ${ }^{1}$ \\ Earth Sciences Division \\ E.O. Lawrence Berkeley National Laboratory \\ University of California \\ 1 Cyclotron Road, MS 14-116 \\ Berkeley, California 94720, USA
}

*corresponding author

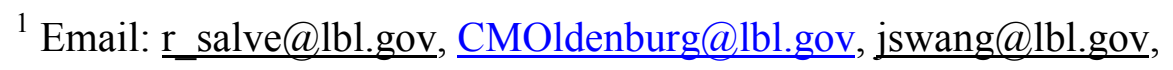
Version 00A 
Fax: (510) 486-6608

Version 00A 


\begin{abstract}
To investigate the potential for fast flow through altered tuff of the nonwelded unit of the Paintbrush Group (PTn) at Yucca Mountain, Nevada, we carried out in situ field experiments using water released directly into the matrix and along a minor subvertical normal fault at Alcove 4 in the Exploratory Studies Facility. During the experiments, changes in moisture content were monitored within the test bed, and a slot excavated below the test bed was visually inspected for seepage. Our field tests suggest that the dry porous PTn matrix is capable of attenuating episodic percolation fluxes in localized areas (such as around faults) where fast flow would be expected to dominate. Once wetted, the matrix is able to retain the moisture over a period of months. As saturation increases in the matrix, less water imbibes along the fault and more water travels farther along the fault. From this observation, we infer that a sequence of infiltration events separated by periods of up to a few months could convey water over increasing distances along the fault.

Keywords: fault-matrix interaction, nonwelded tuff, unsaturated zone, conceptual models, Yucca Mountain.
\end{abstract}

Version 00A 


\section{Introduction}

Alternating layers of welded and nonwelded ash flow and air fall tuffs comprise the subsurface formations at Yucca Mountain (Bodvarsson et al., 1999). Closest to the surface is the welded Tiva Canyon Tuffs, followed sequentially by the Yucca Mountain, Pah Canyon, and the Topopah Spring Tuffs of the Paintbrush Group. The nonwelded tuffs of the Paintbrush group (PTn) lie immediately above the welded tuff of the Topopah Spring Tuff (TSw), the host rock for the potential nuclear waste respository.

The PTn is a major feature of conceptual models that have been developed to describe physical processes dominating unsaturated flow at Yucca Mountain. However, while the importance of the PTn to the hydrology of the site has been acknowledged, there does not seem to be a consensus on how water is conveyed through this layer of nonwelded tuff. In an early conceptual model (Scott et al., 1983), water was thought to travel along vertical fractures in the overlying welded Tiva Canyon Tuff (TCw) before entering the PTn, where it continued to move vertically downwards as matrix flow. A subsequent model presented by Montazer and Wilson (1984) had most of the infiltrating water move laterally through the PTn. This conceptualization was supported by one of the earlier two-dimensional numerical models investigating the unsaturated zone hydrology at Yucca Mountain (Rulon et al., 1986), which suggested that lateral flow occurred through the PTn, and that with increasing fluxes, the portion of diverted water was reduced. Other reports released in the mid-1980s also supported the notion of lateral flow at the base of the PTn (e.g., Sinnock et al., 1984, 1987, Klavetter and Peters (1986), and Peters and Klavetter (1988) [as reported in Flint et al., 2001]). While a majority of Version 00A 
more recent modeling studies (e.g., Ho, 1995; Altman et al., 1996; Moyer et al., 1996; Wilson, 1996) have affirmed earlier conceptualizations of lateral flow in the PTn, others (e.g., Gauthier et al., 1992) have suggested that because of the ability of fractures to drain rapidly the underlying TSw, little lateral diversion occurs in the PTn.

Following the detection of atmospheric radionuclides (Fabryka-Martin et al., $1993 ; 1994)$ in surface-based boreholes, as well as the observation of a large number of fast flow paths following the construction of the Exploratory Studies Facility (ESF) in 1995, conceptual models were developed to include possible fast flow paths from the $\mathrm{TCw}$ into the TSw. This conceptualization required that flow occur through faultassociated fractures in the PTn that allowed water to bypass the rock matrix (FaybrykaMartin et al., 1997). In the more recent models conceptualizing flow through the unsaturated zone at Yucca Mountain (e.g. Flint et al., 2001), flow penetrates rapidly through the PTn along fast pathways, with the unsaturated matrix attenuating flow without inducing significant lateral flow. However, as alluded to in Flint et al., (2001), there is little field evidence to support any of these conceptualizations.

More fundamental than the question of lateral diversion in the PTn is the issue of whether the nonwelded rocks of the PTn effectively dampen pulses of infiltration, providing a generally uniform percolation flux into the underlying TSw, or whether preferential flow paths within the PTn serve to focus flow. While the PTn matrix may be capable of attenuating much of the nonuniform percolation flux (coming from the overlying fractured Tiva Canyon Tuff), fast flow may dominate in localized areas (such as around faults and fractures). With the objective of understanding flow within the PTn, we carried out in situ experiments of water release directly into the matrix and along a Version 00A 
minor subvertical normal fault in Alcove 4 of the ESF. The purpose of this paper is to summarize our in situ field experiments in the PTn and to present a discussion of plausible conceptual models and the implications for flow in the PTn as it affects the potential nuclear waste respository at Yucca Mountain.

\section{In Situ Experiments}

\subsection{Site Description}

The test bed is located in the north face of Alcove 4 of the ESF (Figure 1). The site is approximately $210 \mathrm{~m}$ below ground surface and transects portions of the lower Pah Canyon Tuff (Tpp) and the upper Pre-Pah Canyon bedded tuffs (Tpbt2) (nomenclature of Buesch et al., 1996) of the PTn. The north face of the alcove is approximately $6 \mathrm{~m}$ wide and $5.3 \mathrm{~m}$ high (Figure 2a). Cutting the north face of this test bed is a normal fault that has a strike of approximately 15 degrees, a westward dip of 58 degrees, and a small offset $(0.25 \mathrm{~m})$. The fault is clearly visible along the walls and ceiling of the alcove and is generally a single fracture but in some places forms a narrow fault zone $(<0.05 \mathrm{~m})$.

The PTn at this location consists of nonwelded and pumice-rich tuffs that are zeolitically and argillically altered to varying degrees (Moyer et al., 1996; Barr et al., 1996). X-ray diffraction (XRD) analyses show the Tpp to contain approximately $3 \%$ of smectite. Smectite also composes $14 \%$ of the Tpbt $2 \mathrm{D}$ and $76 \%$ of the Tpbt $2 \mathrm{C}$, as shown in Figure 2a. While the argillic layer was not analyzed, we believe it contains at least as much smectite as the Tpbt2C. The alteration in the vicinity of Alcove 4 has left the PTn with porosity ranging from approximately $25-45 \%$, and permeability on the order of $10^{-14}$ $-10^{-16} \mathrm{~m}^{2}$, much lower than the effective permeability of the fault. .

\section{Version 00A}


Water-release experiments into fractures in unstaturated formations have been conducted at scales extending from less than $1.0 \mathrm{~m}$ (e.g., Lenormand and Zarcone, 1989; Persoff and Pruess, 1995; Haldeman et al., 1991) to scales greater than $10 \mathrm{~m}$ (e.g., Kilbury et al., 1986; Davidson et al., 1989; Faybishenko et al., 2000). At the one-to-tenmeter scale, several in situ experiments have investigated the interplay of fracture flow and fracture matrix interactions (e.g., Wang et al., 1999; Dahan et al, 1998; 1999; Podgorney et al., 2000). However, in each of these experiments, estimates of fracture flow and matrix imbibition remained largely unknown because some of the introduced water was able to bypass the monitoring system. To reduce this uncertainty, we used a horizontal slot and a series of horizontal boreholes for moisture collection and monitoring. The slot was located immediately below the test bed to capture any seepage resulting from gravity drainage. It was excavated to expose a $6.0 \mathrm{~m}$ wide, $4.0 \mathrm{~m}$ deep, and $0.3 \mathrm{~m}$ high cavity located approximately $1.5 \mathrm{~m}$ above the alcove. I-beams are used for supportalong the length of the slot to prevent it from collapsing.

A series of $0.076 \mathrm{~m}$ diameter horizontal boreholes, each $6.0 \mathrm{~m}$ long, were drilled perpendicular to the alcove face. Three of these (Boreholes 1, 11, and 12 of Figure 2) were positioned to intersect the fault at various depths (where depth refers to horizontal distance from the borehole collar) for the purpose of conducting flow tests within the fault (Figure 2b). Boreholes 5, 6, 7, and 8 were configured to aid investigations of water flow through the PTn matrix in the absence of a fast flow path (Figure 2c). Borehole 2 was located to detect moisture that could migrate through the matrix below Borehole 12 . Prior to the liquid-release events, permeabilities of these boreholes were determined from 
air-permeability measurements conducted over $0.3 \mathrm{~m}$ sections along the boreholes (Cook, 2000).

\subsection{Experimental Setup}

Water was released under constant head conditions into Borehole 5 and Borehole 12. The fluid-release apparatus included an inflatable packer system used to isolate the $0.30 \mathrm{~m}$ long injection zone, a pump to deliver water to a constant-head chamber from which water was introduced into the injection zone, and a reservoir to provide a continuous supply of water (Salve and Oldenburg, 2001). In both boreholes, each release event began with water filling the $1.37 \mathrm{~L}$ injection cavity in about 3 minutes. (This was determined from a sight tube located at the borehole collar.) The liquid-release apparatus kept the injection zone filled by maintaining a constant-head boundary for the period of injection. At the end of each test, the pump was shut off, and the $1.37 \mathrm{~L}$ of water remaining in the injection zone were released to the formation under falling-head conditions.

Water was first released into Borehole 5 along a zone 1.5 to $1.8 \mathrm{~m}$ from the collar on October 19, 1998, when 1.37 L were introduced to fill the injection-zone cavity (Table 1). Because of malfunctions in the water supply system, water release to this zone was terminated. Three days later, when the packer system was removed from the borehole, no standing water was observed inside the borehole. Thus, during a period of three days, $\sim 1.5 \mathrm{~L}$ of water imbibed into the formation in Borehole 5 along a zone $1.5-1.8 \mathrm{~m}$ from the collar. A second release into the same borehole began on October 27, 1998, along a zone 2.4-2.7 $\mathrm{m}$ from the collar. At this location, 6.5 L of water were continuously Version 00A 
introduced into the matrix over a period of 23 days. A third release into this borehole was initiated one year later when $2.1 \mathrm{~L}$ of water were released $1.5-1.8 \mathrm{~m}$ from the collar over a period of three days.

A total of $193 \mathrm{~L}$ of water were released under constant-head conditions into Borehole 12 during seven distinct releases over two weeks between October 21 and November 5, 1998 (Table 2). These releases were along a 0.3 m interval centered at a depth of $1.4 \mathrm{~m}$, determined from air-permeability measurements and visual inspection to be the likely location at which Borehole 12 intersected the fault. Between November 30 and December 2, 1999, an additional $136 \mathrm{~L}$ of water were introduced into the same interval during three distinct events. Each release event into Borehole 12 lasted 4-7 hours, during which time $17-56 \mathrm{~L}$ of water entered the injection zone.

Immediately before, during, and after the release of water (under constant-head conditions) into isolated zones in Boreholes 5 and 12, adjacent boreholes were monitoring for changes in saturation using electrical resistance probes (ERPs) and water potential using psychrometers. The ERPs and psychrometers were housed in trays fabricated from $0.10 \mathrm{~m}$ OD PVC pipes (Salve and Oldenburg, 2001). Each pipe section was cut lengthwise to produce a $0.075 \mathrm{~m}$ wide curved tray. On each tray, ERPs and pychrometers were installed at $0.25 \mathrm{~m}$ intervals along the monitoring boreholes. The slot ceiling was periodically inspected for any evidence of seepage after water was introduced into Borehole 12. To measure seepage into the slot following liquid release into the injection borehole, we installed a water collection system in the slot. This system was comprised of stainless steel trays connected to clear PVC collection bottles.

\section{Observations}

Version 00A 


\subsection{Pre-test Moisture Profile}

Measurements of water potential made along five monitoring boreholes prior to the liquid releases showed two distinct zones of wetness extending horizontally into the test bed (Figure 3 ). The first zone, which extended $\sim 1.5 \mathrm{~m}$ from the test bed face, showed a sharp increase in water potentials with depth, while in the second region $(\sim 1.5$ to the maximum monitored depth of $4.0 \mathrm{~m}$ ) water potentials remain fairly constant at potentials above $-60 \mathrm{~m}$. These observations suggest the location of a drying front at least $1 \mathrm{~m}$ from the face of the test bed, which most likely developed from active ventilation in the ESF over the two years since excavation of the alcove.

\subsection{Intake Rates}

During the seven liquid-release events in 1998, intake rates into the fault declined within each test, and also over the course of the series of experiments (Figure 4a). Thus, the initial intake rate of $\sim 250 \mathrm{~mL} / \mathrm{min}$ asymptotically dropped to $\sim 40 \mathrm{~mL} / \mathrm{min}$ after 190 L of water had been released along the fault interval.

When $136 \mathrm{~L}$ of water were released into this zone one year later, the changes in the intake rates mimicked the first three releases from the previous year. Interesting anomalies that was captured during the first and second releases (in 1998) and the eighth and ninth releases (in 1999) were brief increases in intake rates. This increase was most prominent during the first release when the intake rate sharply increased to $150 \mathrm{~mL} / \mathrm{min}$ after dropping below $125 \mathrm{~mL} / \mathrm{min}$ (Figure 4a). In the second release, the intake rates also increased after declining from $150 \mathrm{~mL} / \mathrm{min}$ to $\sim 110 \mathrm{~mL} / \mathrm{min}$. In this case, the increase was not as large as in the first test.

Version 00A 
Measurements of liquid-release rates in the two zones in Borehole 5 exhibited a response similar to that observed for soils. When water was first introduced into the borehole (2.4-2.7 $\mathrm{m}$ from the collar), the initially high rate asymptotically approached low steady-state values of $\sim 0.1 \mathrm{~mL} / \mathrm{min}$ (Figure $4 \mathrm{~b}$ ) over a period of 10 days. This intake rate persisted for the remaining 13 days of continuous liquid release. When water was released into Borehole 5 one year later (1.5-1.8 $\mathrm{m}$ from the collar), the changes in intake rates mimicked the earlier release (see insert Figure 4b) with the initially high rate rapidly decreasing during the first four hours of the experiment.

In Figure 4 (c and d), the cumulative infiltration in the fault and matrix is plotted versus the square-root of time. In a porous medium, if water is only drawn by matrix suction, the slope of this plot, which is a measure of sorptivity of the medium, remains constant (Hillel, 1980). The infiltration response of each of the releases along the fault and matrix shows that the sorptivity clearly does not remain constant during the early stages of liquid release (i.e. into an initially dry zone). A possible explanation for the early-time anomalies in the matrix response is the disturbed zone around the borehole, a consequence of drilling associated with the construction of the borehole. In the case of fault releases, an added complexity arises with the injection zone expanding as water flows vertically down the fault.

\subsection{Wetting in the Matrix}

The apparent travel times of water in the test bed, following releases in the matrix (Borehole 5) and fault (Borehole 12), were determined by tracking changes in electrical resistivity in the monitoring boreholes located adjacent to the injection boreholes.

Version $00 \mathrm{~A}$ 
After the release of water into the two $0.30 \mathrm{~m}$ zones centered at a distance of 1.65 and $2.55 \mathrm{~m}$ from the collar in Borehole 5 in October 1998, increases in saturation (as indicated by a decrease in resistance measured by the ERPs) were observed only in Borehole 6 (Figure 5 a-f). The wetting front was first detected on October 31, 1998, at a distance of $1.9 \mathrm{~m}$, and then on November 2, 1998, at a distance of $0.65 \mathrm{~m}$ from the collar (Figure 5g). It is likely that this wetting front resulted from the slug of water released into the borehole on October 19, 1998, and not from the continuous release between October 27 and November 17, 1998, because wetting at both of these Borehole 6 locations did not persist for more than two days. In Boreholes 7 and 8, single sensors located 1.15 and $1.90 \mathrm{~m}$, respectively, from the borehole collars showed a more continuous increase in saturation over the injection period.

Water introduced into Borehole 5 in 1999 over a zone centered $1.65 \mathrm{~m}$ from the collar was detected in 2-3 days in Boreholes 7 and 8 immediately below the point of release. In Borehole 8, a second ERP located $2.15 \mathrm{~m}$ from the collar briefly showed an increase in saturation one week later, while in Borehole 7, increases in saturation were observed at the end of December, 1999, a month after water was introduced into Borehole 5.

\subsection{Wetting in the Fault Zone}

Water injected into the fault in Borehole 12 was detected by ERPs in both Borehole 11 and Borehole 2 (Figure 6). In Borehole 11, the wetted zone extended from 0.65 to $2.40 \mathrm{~m}$ from the collar, while in Borehole 2 the wetted zone extended between 0.90 and $1.65 \mathrm{~m}$ from the collar.

Version 00A 
The ERP located on the fault (1.40 m from the collar) in Borehole 11 showed a stepped response to each of the ten individual release events (Figure $6 a$ and $b$ ). Following the release of water in the fault zone in Borehole 12 during each of these tests, the saturation rapidly increased during the duration of the release events. When water was not being released into the fault (i.e. between release events), saturation in the fault would decrease over a period of hours. Other ERPs, located adjacent to the fault in Borehole 11, showed a gradual decrease in resistance measurements over a period of a few days (Figure 6e). Following the last test in 1998 (Test 7), there was a period of 12 months when no water was released into the fault. During this time, the wetted zone adjacent to the fault maintained saturation levels that were greater than those observed before the start of the first test (Figure 6c and d). Unlike the fault, which showed a decrease in saturation immediately after the release event, the adjoining matrix exhibited a slow drying trend extending into months.

In Borehole 2, located $0.97 \mathrm{~m}$ below Borehole 12, the first ERPs to locate the wetting front were centered immediately below the fault (Figure 6 e and f). Here, at a distance of 1.15 to $1.65 \mathrm{~m}$ from the borehole collar, changes in saturation were detected almost one week after the first injection event. Over the next three weeks, ERPs at 1.15 and $1.40 \mathrm{~m}$ continued to detect increasing saturations, while the ERP at $1.65 \mathrm{~m}$ indicated increasing saturations for four days before maintaining a relatively constant saturation level for the next 18 days. At depths between 1.90 and $2.40 \mathrm{~m}$, the response was delayed and very slight.

Version 00A 
Unlike the fault, which showed a decrease in saturation immediately after the release event, the adjoining matrix as observed from Boreholes 2 and 11 exhibited a slow drying trend extending into months.

\subsection{Flow along the Fault}

When water was introduced into Borehole 12, the apparent time taken for the wetting front to travel $1.06 \mathrm{~m}$ along the fault to Borehole 11 varied between the 10 tests [Table 1]. The amount of water that occupied the flow path in the vicinity of the fault during the 10 tests can be determined from the apparent travel time along the fault between Borehole 11 and Borehole 12. For Tests $1-5$ and $7-10$, the volume of water released for the duration of the travel time ranged between 5 and $42 \mathrm{~L}$ [Table 1]. Because the duration of the water release during Test 6 (348 minutes) did not extend for the time it took the wetting front to reach Borehole 11 ( 800 minutes), the amount of water released into the fault $(17.1 \mathrm{~L})$ during this test was significantly smaller than the potential flow path volume. By taking the product of released volume and travel time and dividing it by the duration of release, the potential flow path volume for this test was estimated to be $\sim 40 \mathrm{~L}$.

During the first test, $35 \mathrm{~L}$ of water were released into the fault before the wetting front was detected in Borehole 11 located $1.06 \mathrm{~m}$ below. In subsequent tests, the volume of water that occupied the flow paths between Borehole 11 and Borehole 12 decreased when tests occurred in quick succession (i.e., Tests 2, 4, 5, 7, 9, and 10), but increased when the time between releases extended to days or weeks (Tests 3,6, and 8). The largest flow path volume was found during Test 8 , when $42 \mathrm{~L}$ entered the fault before the

Version $00 \mathrm{~A}$ 
wetting front was detected along Borehole 11. During Test 5, the smallest volume of water was released in Borehole 12 before the front was detected in Borehole 11.

\subsection{Wetting at the Slot Ceiling}

During October and November of 1998, when 193 L of water were released into the fault and $8 \mathrm{~L}$ were released into the matrix, no water was observed in the slot. One year later, during the second day of an additional $136 \mathrm{~L}$ release of water along the fault, a wet spot was observed on the slot ceiling approximately $0.10 \mathrm{~m}$ from the fault at a depth of $\sim 0.75 \mathrm{~m}$ from the face of the test bed. This damp spot persisted during the third day of release, but did not develop into a seep. No measurable drips were observed in the slot during these experiments.

\section{Discussion}

From the liquid-release experiments in the PTn, it appears that there are a few small, discrete flow paths within the PTn matrix that allow water to move rapidly over relatively long distances. For example, when water was introduced into the matrix in Borehole 5, it was quickly detected in Borehole 6 within 12-14 days at two discrete locations $\sim 0.4 \mathrm{~m}$ and $\sim 1.0 \mathrm{~m}$ from the release zone, indicating flow velocities of 0.04 to $0.08 \mathrm{~m} /$ day along the small flow paths. However, the entire matrix is incapable of transmitting water at similar rates, as indicated by the absence of a wetting front arriving in Boreholes 7 and 8.

Intake rates, wetting-front velocities, and flow-path volumes measured during the ten release experiments along the fault suggest that the movement of water through this potentially fast flow path is influenced by interactions between the fault and surrounding matrix. For the first seven tests, the average intake rates continued to decrease as the tests Version 00A 
progressed. A year later, when the remaining three tests were conducted, the intake rates were similar to those in the first three tests. This implies that the composite system consisting of fault and matrix behaved grossly similar to a porous medium traditionally described by a sorptivity model (e.g., Philip, 1969) that becomes wet and then dries again over the intervening year (Figure $4 \mathrm{c}$ ).

However, the sorptivity model cannot explain the changes in flow-path volumes or wetting-front velocities, which appear to be influenced by wetting history and possible short-term wetting-related changes along the fault. As seen in Figure 7, the wetting-front velocities increased as the volume of water occupying the flow path decreased when tests were conducted in quick succession. For example, the travel velocity of the wetting front increased from $6 \mathrm{~m} /$ day to $15 \mathrm{~m} /$ day, and the flow path volume decreased from $34.9 \mathrm{~L}$ to 12.5 L between Tests 1 and 2. After four days, when the next test was initiated, the travel velocity was similar to the first test. During the next two closely spaced tests, the travel velocity increased dramatically while the flow path volume decreased. When Test 6 was conducted after a lapse of five days (since Test 5), the travel velocity was significantly slower than Test 1 , while there was an increase of $\sim 5 \mathrm{~L}$ in the volume of water occupying the flow path. This implies that the fast flow path between Borehole 11 and Borehole 12 had been altered over a period of two weeks, such that permeability was reduced or water was forced through a more tortuous path. When water was released into the same location in Borehole 12 one year later, the travel velocity of the wetting front and the volume of water occupied along the flow path were similar to Tests 1,2 , and 3 . The changes along the flow path that were apparent during Test 6 and Test 7 were not present (i.e., the flow paths had recovered to pre-test conditions).

Version 00A 
The field tests suggest that water from an episodic infiltration event entering a fast flow path (i.e., fault or fracture) located in the PTn (Figure 8a) will travel along the flow path in two stages. During the first stage, the wetting front moves slowly $(0.42 \mathrm{~cm} / \mathrm{min})$ as water is absorbed into the matrix from the fault. The second stage involves water traveling much faster $(1.06 \mathrm{~cm} / \mathrm{min})$ along the fault wetted previously. During this event, the active flow path includes the fault and the wet matrix close to the fault (Figure 8b). For subsequent liquid release events that occur within hours, the active flow path is initially restricted to the fault wetted during the earlier event. If the volume of water released is greater than the storage capacity of the fault zone, the additional water travels downwards through the dry matrix.

Equal volumes of water released in quick succession along a wetted fault could potentially travel at faster rates under the influence of gravity and contribute to a larger wetted area. However, there appear to be two mechanisms that dampen this trend. The first is the significant reduction in the rate at which water is able to enter the fast flow path (as indicated by the steady decrease in intake rates) and the second is the apparent reduction in permeability along the wetted fault. While both clay swelling and alternate flow paths provide possible explanations for the apparent reduction in permeability, the available experimental data are insufficient to discriminate between these two processes.

Water that imbibes into the matrix is retained for long periods (extending to at least a few months), unlike the fault which loses water immediately after an infiltration event (Figure 8c). A consequence of this is that matrix rock that served to attenuate infiltration pulses along an initially dry fault was unable to imbibe water at similar rates

Version 00A 
when wet. Therefore, pulses of infiltrating water entering a previously wetted fast flow path will travel downward farther than if the flow path is initially dry (Figure 8d).

While these field experiments at Alcove 4 in the ESF have provided significant insights into flow in the PTn at Yucca Mountain, there are some inherent limitations that prevent a more comprehensive understanding. Because our tests were restricted to a single location, our results cannot be generalized to the PTn layer blanketing the potential repository horizon. Further, as indicated by pre-test measurements of water potential (Figure 3) the liquid release tests were conducted close to a drying front. Under undisturbed conditions, where ventilation effects are absent, a wetter test bed could alter our observations. However, in the vicinity of the fault, we believe our observations may not be unrealistic, given the possibility of natural ventilation effects along permeable features such as faults. Finally, the effects of introducing a series of boreholes and a large slot within the test bed, while assumed to be minimal, remain uncertain.

\section{Conclusions}

Our field tests suggest that the PTn matrix has minor discrete flow paths that can transmit water quickly, while the adjoining bulk matrix has much lower permeability. When the fault and matrix are dry, water introduced into the fault is largely imbibed by the surrounding matrix. Although the fault begins to dry immediately after an infiltration event, the matrix remains wet for long periods of time (extending to months). The apparent permeability of the fault-matrix system as measured by travel time changes as the period of wetting increases with infiltration events in quick succession resulting in higher apparent permeabilities. Thus, while early episodic infiltration events can be dampened by an initially dry PTn matrix, a fault may convey a pulse of water over larger Version 00A 
distances if the matrix is wet. However, this effect may be offset by the observation that over a longer period (days to weeks), the fault zoneappears to change such that the apparent permeability is lower than an initially dry fault. It is important to note that our interpretations of these field tests are only applicable to the vicinity of Alcove 4 and may not apply to the PTn in general across Yucca Mountain.

Version 00A 


\section{Acknowledgments}

We thank Diana Swantek (LBNL) for her contributions in the preparation of graphics for this paper. We thank Christine Doughty and Paul Cook for thorough internal technical reviews, and Dan Hawkes for improving the quality of this paper with his editorial comments. This work has been supported by the Director, Office of Civilian Radioactive Waste Management, through Memorandum Purchase Order EA9013MC5X between TRW Environmental Safety Systems, Inc., and the Ernest Orlando Lawrence Berkeley National Laboratory for the Yucca Mountain Site Characterization Project under U.S. Department of Energy Contract No. DE-AC03-76SF00098.

Version $00 \mathrm{~A}$ 


\section{REFERENCES}

Altman, S.J., Arnold, B. W., Barnard, R. W., Barr, G. E., Ho, C. K., McKenna, S. A., and Eaton, R. R., 1996. Flow calculations for Yucca Mountain groundwater travel time (GWTT-95), Sandia National Laboratories, Albuquerque, NM, SAND96-0819.

Barr, D. L., Moyer, T. C., Singleton, W. L., Albin, A. L., Lung, R. C., Lee, A. C., Beason, S. C., and Eatman, G. L. W., 1996. Geology of the North Ramp Stations 4+00 to 28+00, Exploratory Studies Facility, Yucca Mountain Project. Yucca Mountain, Nevada: Summary Report, U.S. Bureau of Reclamation to the U.S. Department of Energy.

Bodvarsson, G. S., Boyle W., Patterson, R., and Williams, D., 1999. Overview of scientific investigations at Yucca Mountain - the potential repository for high-level nuclear waste, Journal of Contaminant Hydrology, 38:3-24.

Buesch, D. C., Spengler, R. W., Moyer, T. C., and Geslin, J. K., 1996. Proposed stratigraphic nomenclature and macroscopic identification of lithostratigraphic units of the Paintbrush Group exposed at Yucca Mountain, Nevada., U.S. Geol. Surv. Open-File Report 94-469, Denver, Colorado.

Cook, P., 2000. In situ pneumatic testing at Yucca Mountain, Int. J. of Rock Mech. and Mining Sci., 37: 357-367.

Version 00A 
Dahan, O., Nativ, R., Adar, E. M., and Berkowitz, B., 1998. Measurement system to determine water flux and solute transport through fractures in the unsaturated zone, Ground Water, 36: 444-449.

Dahan, O., Nativ, R., Adar, E.M., Berkowitz, B., and Ronen, Z., 1999. Field observation of flow in a fracture intersecting unsaturated chalk, Water Resour. Res., 35: 3315-3326.

Davidson, G.R., Bassett, R.L, Hardin, E.L., and Thompson, D.L., 1998. Geochemical evidence of preferential flow of water through fractures in unsaturated tuff, Apache Leap, Arizona, Applied Geochemistry, 13: 185-195.

Fabryka-Martin, J. T., Wightman, S. J., Murphy, W. J., Wickham, M. P., Caffee, M. W., Nimz, G. J., Southon, J. R., and Sharma, P., 1993. Distribution of chlorine-36 in the unsaturated zone at Yucca Mountain: an indicator of fast transport paths. In: Proceedings of the FOCUS '93, Site Characterization and Model Validation, Las Vegas, NV Sept. 26-29, La Grange Park, Ill., American Nuclear Society, pp. 58-68.

Fabryka-Martin, J. T., Wightman, S. J., Robinson, B. A., Vestal, E. W., 1994. Infiltration processes at Yucca Mountain inferred from chloride and chlorine-36 distributions, Los Alamos National Laboratory Milestone Report, 4317, Los Alamos, NM.

Fabryka-Martin, J. T., Flint, A. L., Sweetkind, D. S., Wolfsberg, A. V., Levy, S. S., Roemer, G. J. C., Roach, J. L., Wolfsberg, L. E., and Duff, M. C., 1997. Evaluation of flow and transport models of Yucca Mountain, based on

Version 00A 
chlorine-36 and chloride studies for FY97, Los Alamos National Laboratory Milestone Report, LA-133352-MS, Los Alamos, NM.

Faybishenko, B., Doughty, C., Steiger, M., Long, J.C.S., Wood, T.R., Jacobsen, J.S., Lore, J., and Zawislanski, P.T., 2000. Conceptual model of the geometry and physics of water flow a fractured basalt vadose zone, Water Resour. Res., 36: 3499-3520.

Flint, A. L., Flint, L. E., Bodvarsson, G. S., Kwicklis, E. M., and Fabryka-Martin, J., 2001. Evolution of the conceptual model of unsaturated zone hydrology at Yucca Mountain, Nevada, Journal of Hydrology, 247:1-30.

Gauthier, J. H., Wilson, M. L., and Lauffer, F. C., 1992. Estimating the consequence of significant fracture flow at Yucca Mountain. In: Proceedings of the Third Internaltional Conference on High-Level Radioactive Waste Management, Las Vegas, NV, La Grange Park, Ill., American Nuclear Society, pp. 727731.

Haldeman, W.R., Chuang, Y., Rasmussen, T.C., and Evans, D.D., 1991. Laboratory analysis of fluid flow and solute transport through a fracture embedded in porous tuff, Water Resour. Res., 27: 53-65.

Hillel, D., 1980. Applications of soil physics, Academic Press, New York, pp.5-27.

Ho. C. K., 1995. Assessing alternate conceptual models of fracture flow. In: Pruess, K. (Ed.), Proceedings of the TOUGH Workshop '95, Lawrence Berkeley National Laboratory, Lawrence Berkeley Laboratory Report, LBL-37200, Berkeley, CA.

Version 00A 
Kilbury, R.K., Rasmussen, T.C., Evans, D.D., and Warrick, A.W., 1986. Water and air intake of surface-exposed rock fractures in situ, Water Resour. Res., 22: $1431-1443$.

Lenormand, R. and Zarcone, C., 1989. Capillary fingering: percolation and fractal dimension, Transport in Porous Media, 4: 599-612.

Klavetter, E. A., and Peters, R. R. 1986. Estimation of hydrologic properties of an unsaturated fractured rock mass, Sandia National Laboratories, Albuquerque, NM, SAND84-SA2642.

Montazer, P., and Wilson, W. E., 1984. Conceptual hydrologic model of flow in the unsaturated zone, Yucca Mountain, Nevada, US Geological Survey Water-Resources Investigation Report 84-4345

Moyer, T. C., Geslin, J. K., and Flint, L. E., 1996. Stratigraphic relations and hydrologic properties of the Paintbrush Tuff nonwelded (PTn) hydrologic unit, Yucca Mountain, Nevada, U.S. Geol. Surv. Open File Rep. 95-397.

Persoff, P., and Pruess, K., 1995. Two-phase flow visualization and relative permeability measurement in natural rough-walled rock fractures, Water Resour. Res., 31: 1175-1186.

Philip, J. R., 1969. Theory of infiltration, Adv. Hydrosci., 5: 215-296.

Peters,, R. R., and Klavetter, E. A., 1988. A continuum model for water movement in an unsaturated fractured rock mass. Water Resour. Res., 24:416-430.

Podgorney, R.K., Wood, T.R., Faybishenko, B., and Stoops, T.M., 2000. Spatial and temporal instabilities in water flow through variably saturated fractured basalt on a one-meter field scale, in Dynamics of fluids in fractured rock, Version 00A 
B. Faybishenko et al., Eds., Geophysical Monograph Series, V. 122, American Geophysical Union.

Salve, R., and Oldenburg, C. M., 2001. Water flow in a fault in altered nonwelded tuff Water Resources Res., 37:3043-3056.

Salve, R., Wang, J. S. Y., and Tokunaga, T. K., 2000. A probe for measuring wetting front migration in rocks, Water Resour. Res., 36: 1359-1367.

Rulon, J. J., Bodvarsson, G. S., and Montazer, P., 1986. Preliminary numerical simulations of groundwater flow in the unsaturated zone, Yucca Mountain, Nevada, Lawrence Berkeley Laboratory Report, LBL-20553, Berkeley, CA.

Scott, R. B., Spengler, R. W., Diehl, S., Lappin, A. R., and Chornack, M. P., 1983. Geologic character of tuffs in the unsaturated zone at Yucca Mountain, southern Nevada, In: Mercer, J. W., Rao, P. S. C., and Marine, I. W. (Eds.). Role of the unsaturated zone in radioactive and hazardous waste disposal. Ann Arbor Science, An Arbor, MI, pp. 289-335.

Sinnock, S., Lin, Y. T., and Brannen, J. P., 1984. Preliminary bounds on the expected post-closure performance of the Yucca Mountain repository site, Southern Nevada, Sandia National Laboratories, Albuquerque, NM, SAND84-3918, $83 \mathrm{pp}$.

Sinnock, S., Lin, Y. T., and Brannen, J. P., 1987. Preliminary bounds on the expected post-closure performance of the Yucca Mountain repository site, Southern Nevada. Journal of Geophysical Research 92 (B8), 7820-7842..

Version 00A 
Wang, J. S. Y, Trautz, R. C., Cook, P. J., Finsterle, S., James, A. L., and Birkholzer, J., 1999. Field tests and model analyses of seepage into drift, J. of Contaminant Hydrology, 38: 323-347.

Wilson, M. L., 1996. Lateral diversion of the PTn unit: capillary-barrier analysis. In: Proceedings of the High Level Radioactive Waste Management Seventh International Conference on High-Level Radioactive Waste Management, Las Vegas, NV, La Grange Park, Ill., American Nuclear Society, pp. 111113.

Version $00 \mathrm{~A}$ 


\begin{tabular}{|c|c|c|c|}
\hline Date & $\begin{array}{c}\text { Location of release } \\
(\text { along Borehole 5)* }\end{array}$ & $\begin{array}{c}\text { Volume injected } \\
(\mathrm{L})\end{array}$ & $\begin{array}{c}\text { Duration } \\
\text { (days) }\end{array}$ \\
\hline $10 / 19 / 98$ & $1.5-1.8$ & 1.37 & 0.16 \\
\hline $10 / 27 / 98$ & $2.4-2.7$ & 6.5 & 29 \\
\hline $11 / 30 / 99$ & $1.5-1.8$ & 2.1 & 3 \\
\hline
\end{tabular}

*Distance $(\mathrm{m})$ from borehole collar

Table 1. Details of liquid injection into the matrix (i.e. non-faulted zone).

\begin{tabular}{|c|r|c|c|c|c|c|c|}
\hline Test \# & $\begin{array}{c}\text { Start of test } \\
(\text { date/time })\end{array}$ & $\begin{array}{c}\text { Duration } \\
(\mathrm{hr}: \mathrm{min})\end{array}$ & $\begin{array}{c}\text { Average intake rate } \\
(\mathrm{mL} / \mathrm{min})\end{array}$ & $\begin{array}{c}\text { Volume injected } \\
(\mathrm{L})\end{array}$ & $\begin{array}{c}\text { Travel Time to bh11 } \\
(\mathrm{min})\end{array}$ & $\begin{array}{c}\text { Velocity } \\
(\mathrm{cm} / \mathrm{min})\end{array}$ & $\begin{array}{c}\text { Flow path volume } \\
(\mathrm{L})\end{array}$ \\
\hline 1 & $10 / 21 / 988: 20$ & $5: 02$ & 138 & 42.9 & 250 & 0.42 & 34.9 \\
\hline 2 & $10 / 22 / 988: 17$ & $5: 47$ & 115 & 41.4 & 100 & 1.06 & 12.5 \\
\hline 3 & $10 / 26 / 9811: 10$ & $4: 05$ & 82 & 21.3 & 220 & 0.48 & 19.2 \\
\hline 4 & $10 / 27 / 988: 33$ & $6: 40$ & 70 & 29.5 & 120 & 0.88 & 10 \\
\hline 5 & $10 / 28 / 988: 21$ & $5: 47$ & 60 & 22.2 & 80 & 1.33 & 5 \\
\hline 6 & $11 / 4 / 989: 51$ & $5: 00$ & 49 & 17.1 & 800 & 0.13 & $\sim 40$ \\
\hline 7 & $11 / 5 / 988: 43$ & $6: 03$ & 48 & 18.9 & 360 & 0.29 & 17.3 \\
\hline 8 & $11 / 30 / 9910: 56$ & $4: 28$ & 164 & 45.4 & 254 & 0.42 & 41.9 \\
\hline 9 & $12 / 1 / 998: 13$ & $7: 57$ & 114 & 55.8 & 117 & 0.91 & 16.8 \\
\hline 10 & $12 / 2 / 998: 28$ & $5: 11$ & 107 & 34.7 & 102 & 1.04 & 7.8 \\
\hline
\end{tabular}

Table 2. Details of liquid injection into fault during 10 release events.

\section{Version 00A}




\section{Figure Captions}

Figure 1. Location map of Alcove 4 in the Exploratory Studies Facility.

Figure 2. Test bed details. (a) North face of Alcove 4 Norehole location, (b) Borehole configuration relative to fault plane (shaded), (c) Borehole configuration for investigation of matrix properties.

Figure 3. Pretest measurements of water potential along monitoring boreholes.

Figure 4. Intake rates observed in the a.fault and b.matrix as water was released under constant-head conditions. The cumulative infiltration is plotted against time $1 / 2$ for tests in the c. fault and d. matrix. Note legend is the same for a, b, c and d.

Figure 5. Changes in saturation as detected by electrical resistance probes along the lengths of boreholes $6(\mathrm{a} \& \mathrm{~b}), 7$ (c \& c) and 8 (e \& f), during liquid release experiments into the matrix (in borehole 5) in 1998 and 1999. Figures $g$ \& $\mathrm{h}$ show the responses of the four probes which detected increases in saturation during the releases in 1998 and 1999, Figure 6. Changes in saturation detected by electrical resistance probes along the lengths of Boreholes 11 (A \& B) and Borehole 2 (e \& f), during liquid release experiments along the fault (in borehole 12) in 1998 and 1999. Figures a \& b show the responses of probes located at or close to the fault in Borehole 11. Arrows indicate the time of arrival of the wetting front along the fault in Borehole 11 during the 10 releases in Borehole 12. Figures $\mathrm{c}, \mathrm{d}$, e \& $\mathrm{f}$ show long term changes in saturation in Borehole $11 \& 2$ following the liquid release experiments.

Figure 7. Average intake rates, wetting front velocity and flow path volumes measured during 10 liquid release tests along fault.

Version 00A 
Figure 8. Conceptual model of fault flow in the PTn in Alcove 4.

Version 00A 


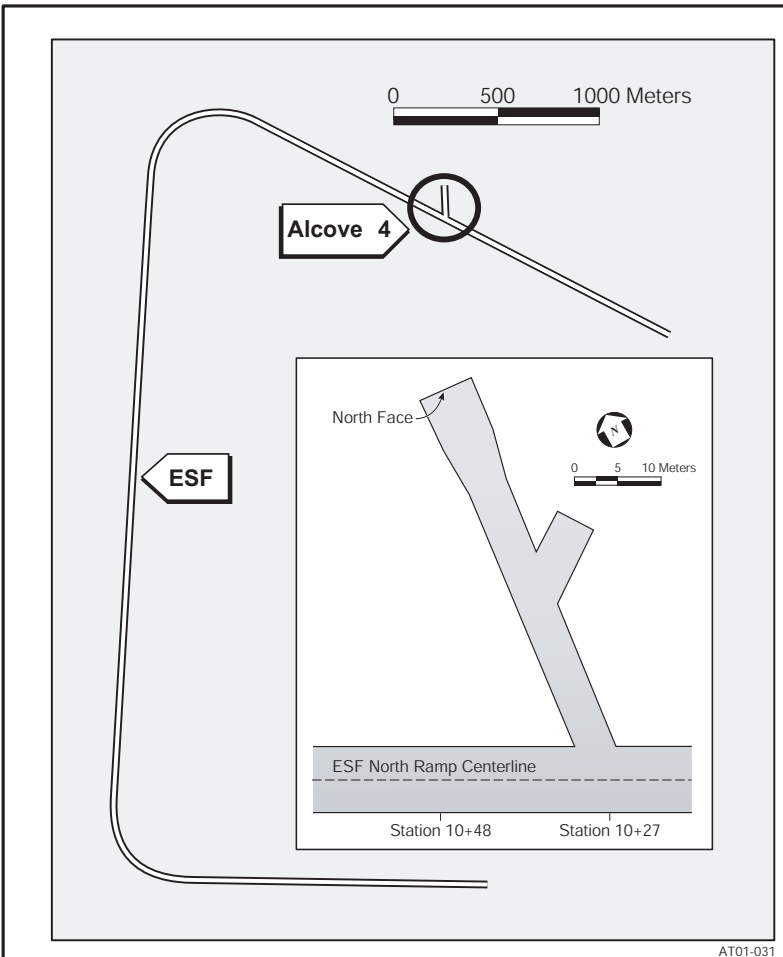

Figure 1. Location map of Alcove 4 in the Exploratory Studies Facility.
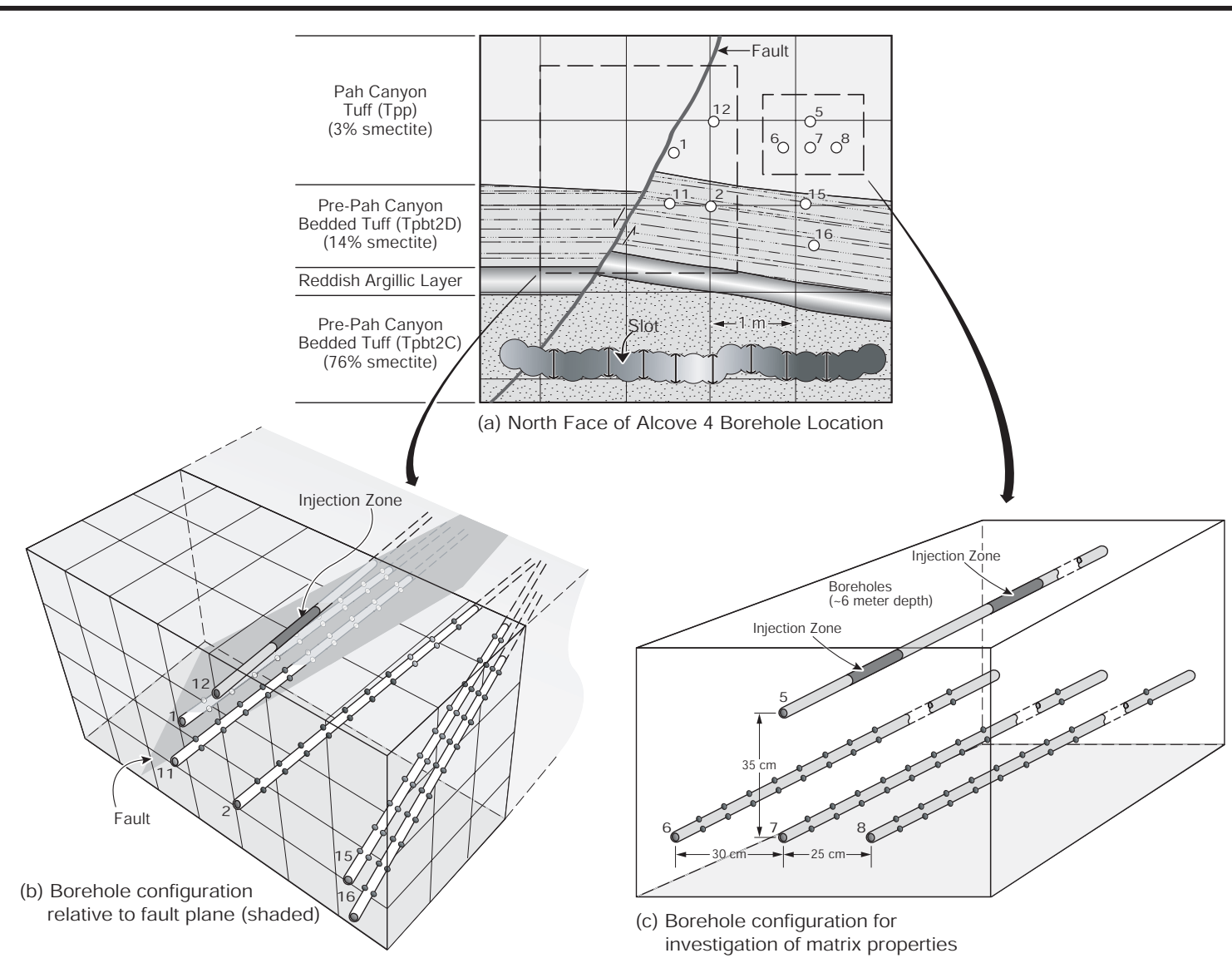

(c) Borehole configuration for investigation of matrix properties

Figure 2. Test bed details 


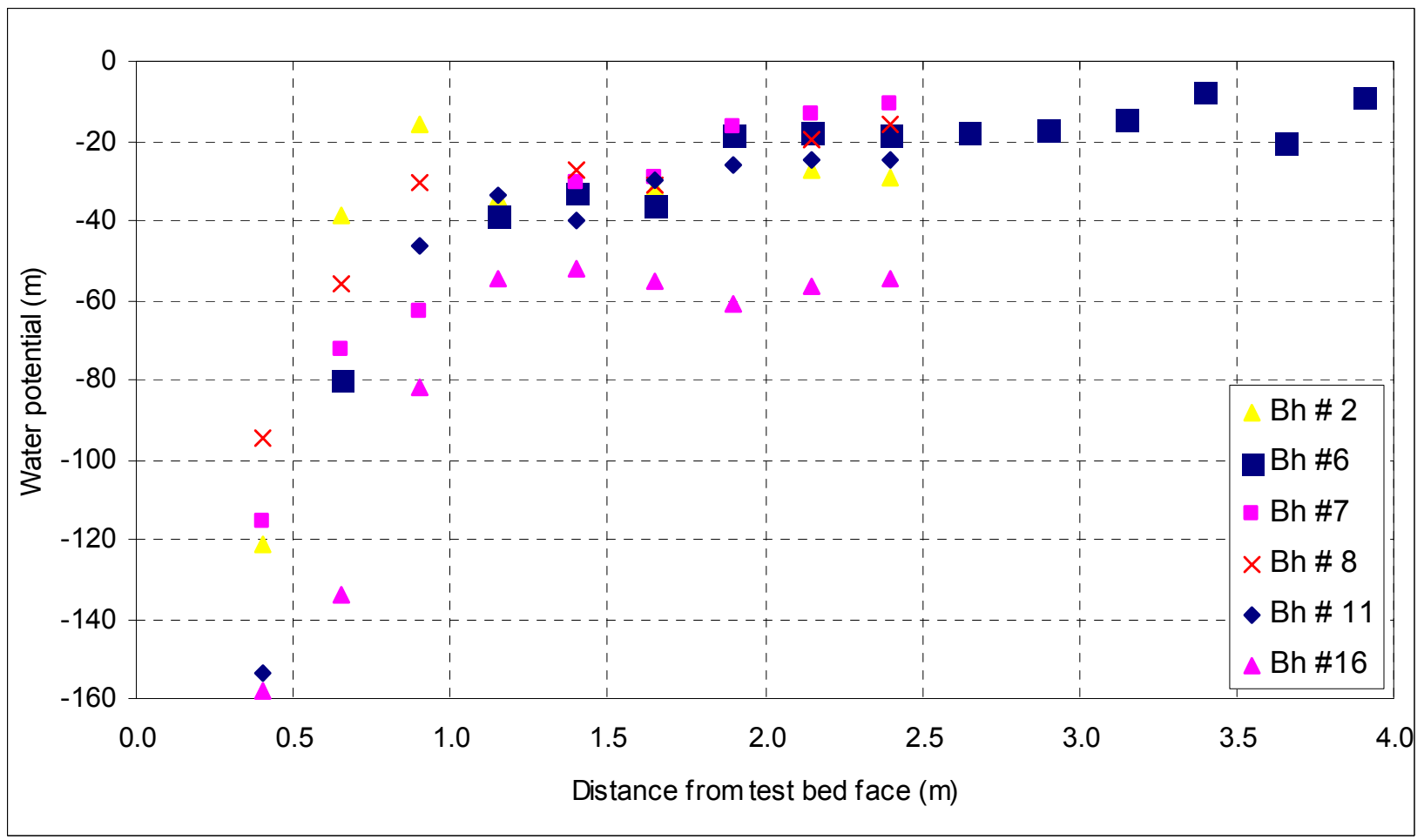

Figure 3. Pretest measurements of water potentials along monitoring boreholes. 

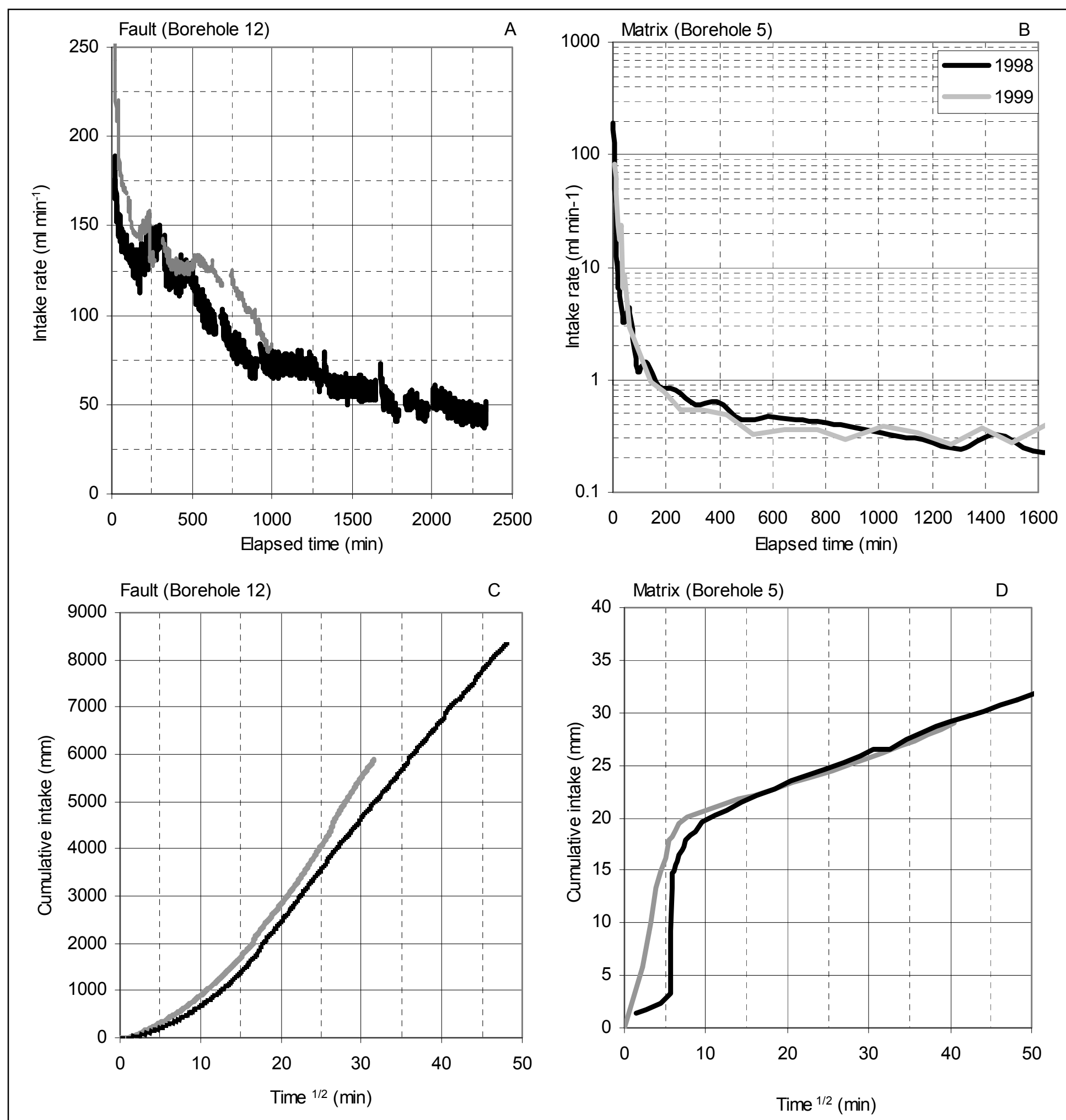

Figure 4. Intake rates observed in the a.fault and b.matrix as water was released under constant-head conditions. The cumulative infiltration is plotted against the square of time for tests in the $\mathrm{c}$. fault and $\mathrm{d}$. matrix. Note legend is the same for $a, b, c$ and $d$. 

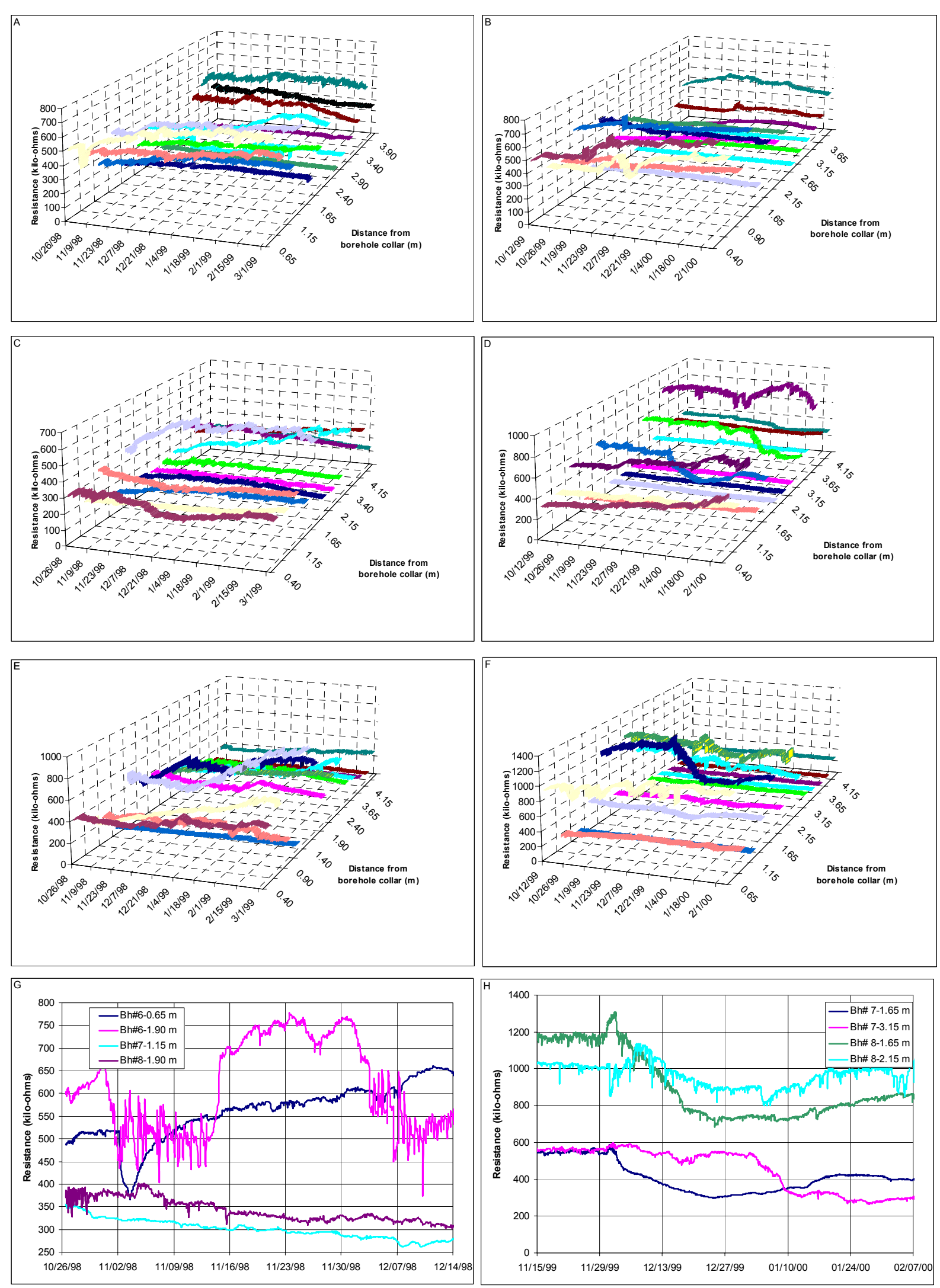

Figure 5. Changes in saturation as detected by electrical resistance probes along the lengths of boreholes 6 (Aand $\mathrm{B}$ ), 7 (C and $\mathrm{D}$ ) and 8 (E and $\mathrm{F}$ ), during liquid release experiments into the matrix (in borehole 5) in 1998 and 1999. Figures $\mathrm{G}$ and $\mathrm{H}$ show the responses of the four probes which detected increases in saturation during the releases in 1998 and 1999. 

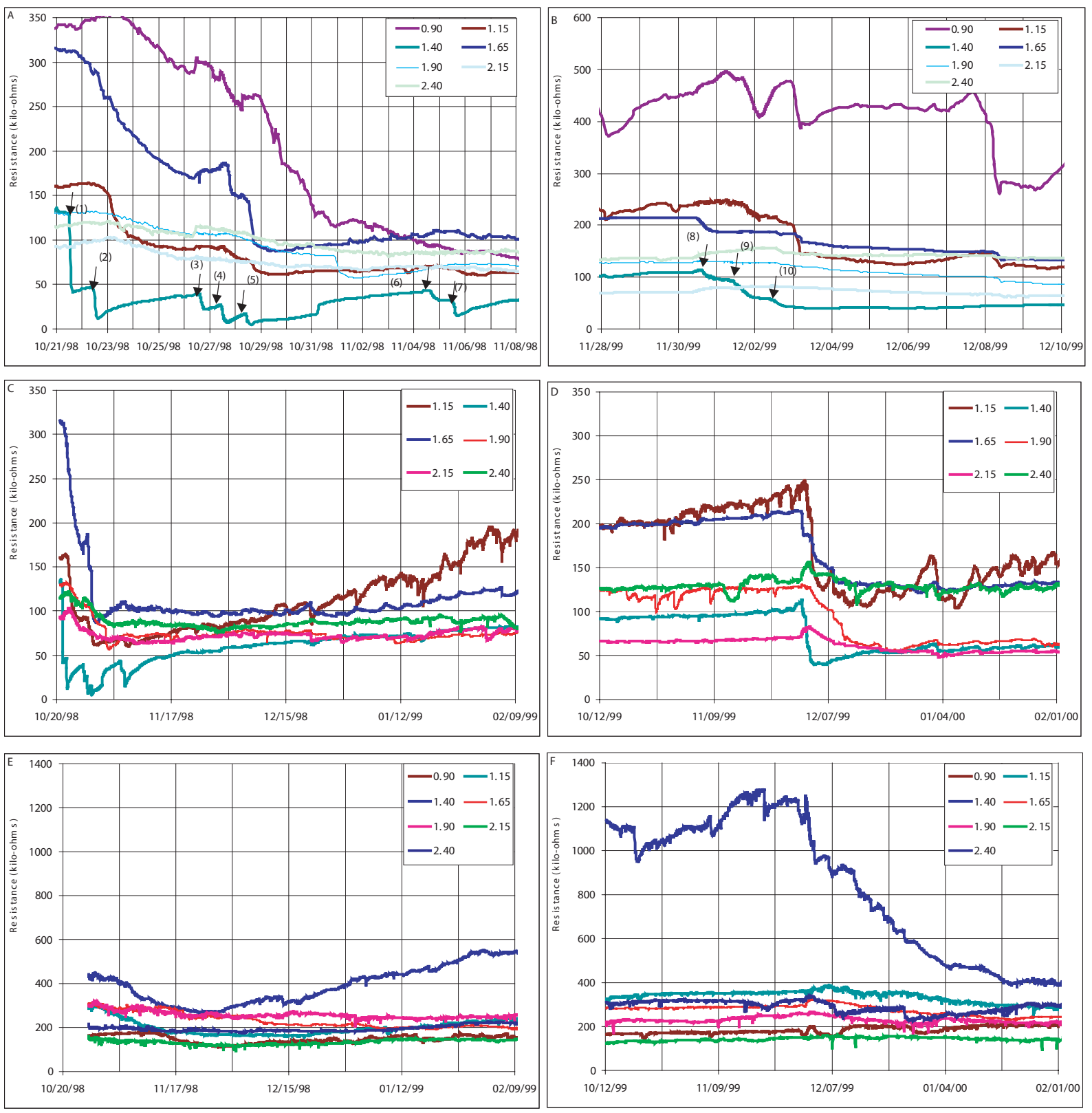

Figure 6. Changes in saturation detected by electrical resistance probes along the lengths of Boreholes 11 ( $\mathrm{A}$ and $\mathrm{B}$ ) and Borehole 2 (E and $\mathrm{F}$ ), during liquid release experiments along the fault (in borehole 12) in 1998 and 1999. Figures A and B show the responses of probes located at or close to the fault in Borehole 11. Arrows indicate the time of arrival of the wetting front along the fault in Borehole 11 during the 10 releases in Borehole 12. Figures $\mathrm{C}$, $\mathrm{D}, \mathrm{E}$ and $\mathrm{F}$ show long term changes in saturation in Boreholes 11 and 2 following the liquid release experiments. 


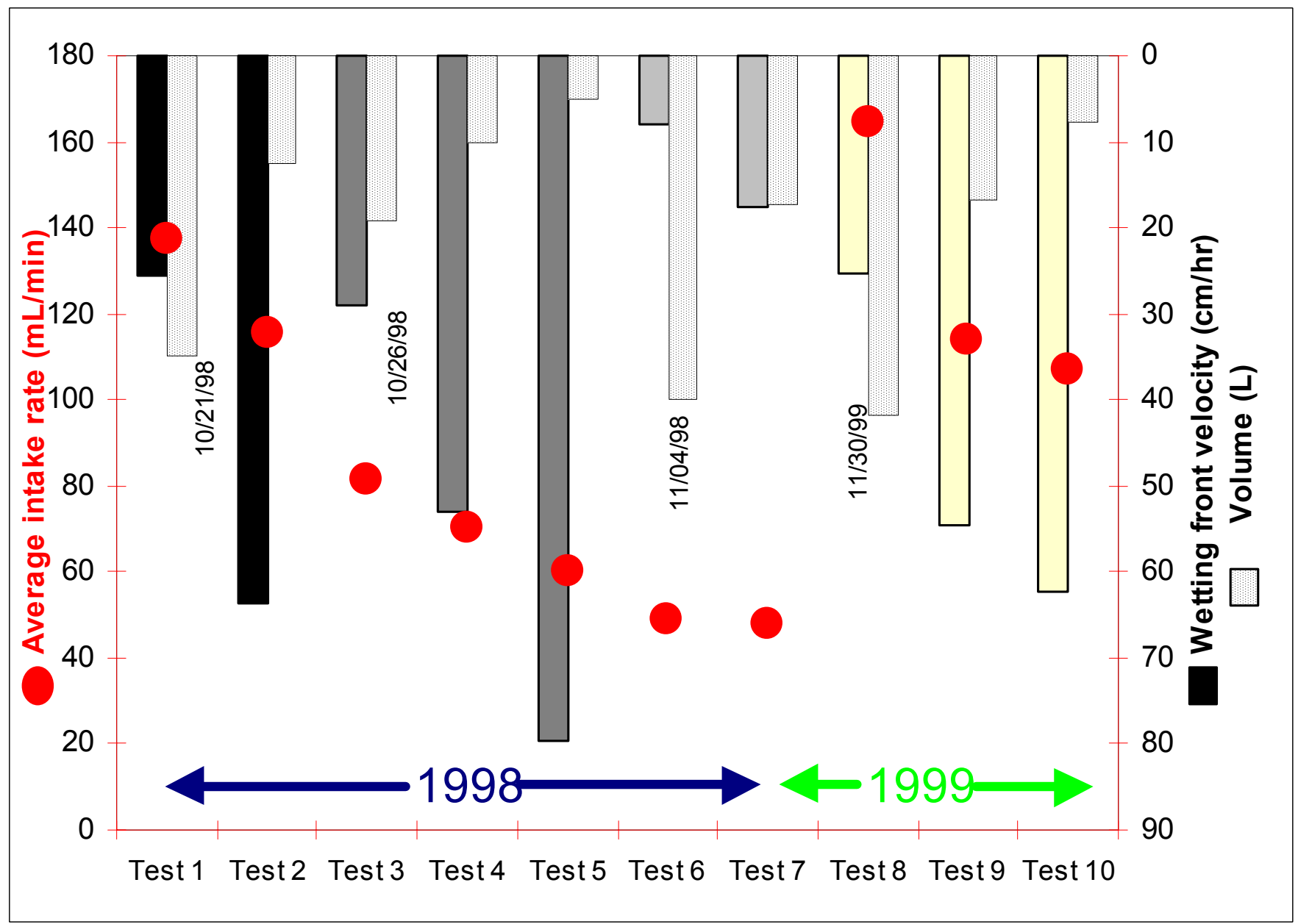

Figure 7. Average intake rates (stipples on primary $\mathrm{Y}$-axis), wetting front velocity (solid bars on secondary Y-axis) and flow path volumes (dashed bars on secondary Y-axis) measured during 10 liquid release tests along the fault. Solid bars with similar shades indicate tests that were conducted $\sim 24$ hours apart. Date below bars indicate the day test was conducted. 

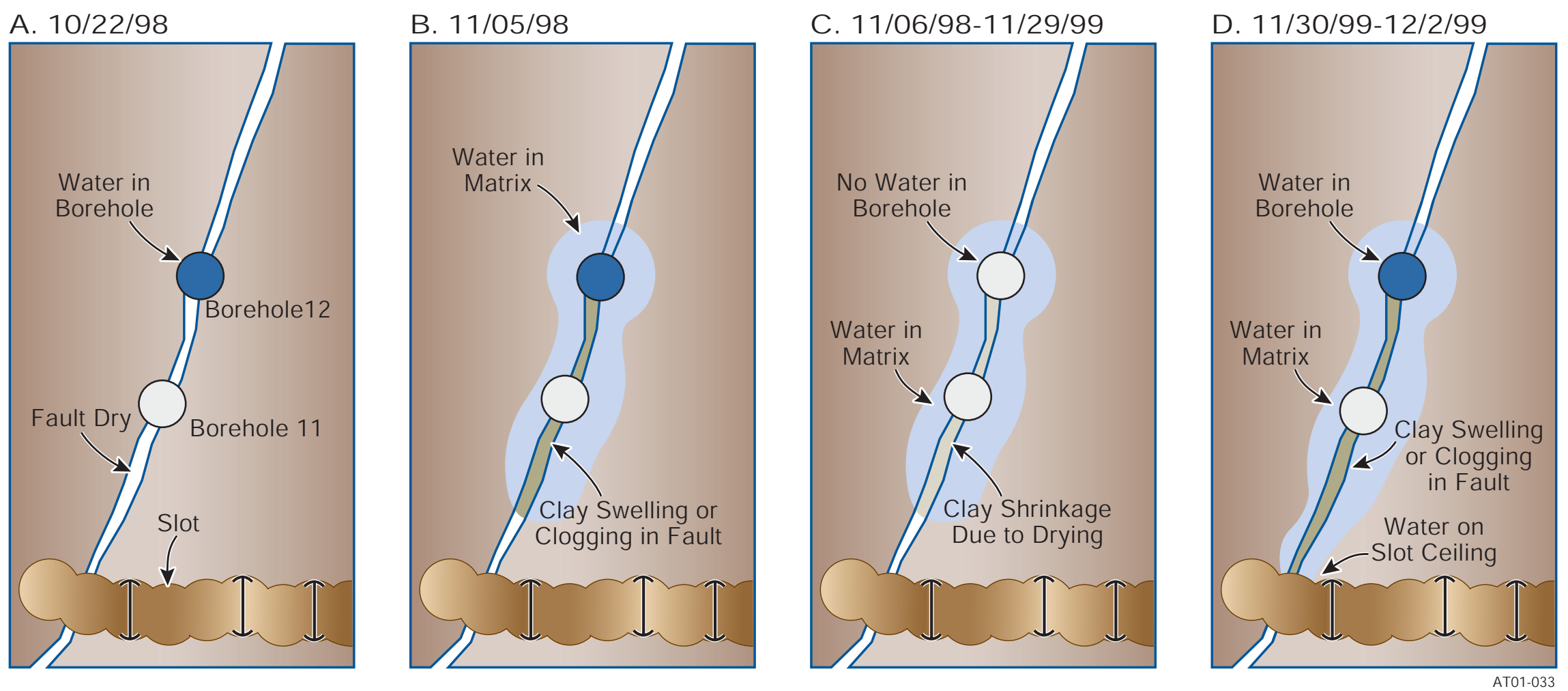

Figure 8. Conceptual model of fault flow in the PTn in Alcove 4 